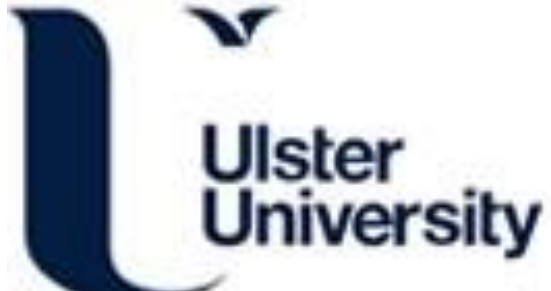

\section{Porous cellulose as promoter of oil production by the oleaginous yeast Lipomyces starkeyi using mixed agroindustrial wastes}

Ganatsios, V., Koutinas, A. A., Bekatorou, A., Panagopoulos, V., Banat, I. M., Terpou, A., \& Kopsahelis, N. (2017). Porous cellulose as promoter of oil production by the oleaginous yeast Lipomyces starkeyi using mixed agroindustrial wastes. Bioresource Technology, 18583. https://doi.org/10.1016/j.biortech.2017.07.163

Link to publication record in Ulster University Research Portal

Published in:
Bioresource Technology

Publication Status:

Published online: 03/08/2017

DOI:

10.1016/j.biortech.2017.07.163

\section{Document Version}

Author Accepted version

\section{General rights}

Copyright for the publications made accessible via Ulster University's Research Portal is retained by the author(s) and / or other copyright owners and it is a condition of accessing these publications that users recognise and abide by the legal requirements associated with these rights.

\section{Take down policy}

The Research Portal is Ulster University's institutional repository that provides access to Ulster's research outputs. Every effort has been made to ensure that content in the Research Portal does not infringe any person's rights, or applicable UK laws. If you discover content in the Research Portal that you believe breaches copyright or violates any law, please contact pure-support@ulster.ac.uk. 


\section{Accepted Manuscript}

Porous cellulose as promoter of oil production by the oleaginous yeast Lipomyces starkeyi using mixed agroindustrial wastes

Vassilios Ganatsios, Athanasios A. Koutinas, Argyro Bekatorou, Vassilios

Panagopoulos, Ibrahim M. Banat, Antonia Terpou, Nikolaos Kopsahelis

PII:

S0960-8524(17)31279-8

DOI: http://dx.doi.org/10.1016/j.biortech.2017.07.163

Reference: BITE 18583

To appear in:

Bioresource Technology

Received Date:

7 May 2017

Revised Date:

25 July 2017

Accepted Date:

26 July 2017

Please cite this article as: Ganatsios, V., Koutinas, A.A., Bekatorou, A., Panagopoulos, V., Banat, I.M., Terpou, A., Kopsahelis, N., Porous cellulose as promoter of oil production by the oleaginous yeast Lipomyces starkeyi using mixed agroindustrial wastes, Bioresource Technology (2017), doi: http://dx.doi.org/10.1016/j.biortech.2017.07.163

This is a PDF file of an unedited manuscript that has been accepted for publication. As a service to our customers we are providing this early version of the manuscript. The manuscript will undergo copyediting, typesetting, and review of the resulting proof before it is published in its final form. Please note that during the production process errors may be discovered which could affect the content, and all legal disclaimers that apply to the journal pertain. 
Porous cellulose as promoter of oil production by the oleaginous yeast Lipomyces starkeyi using mixed agroindustrial wastes

Vassilios Ganatsios $^{\text {a,b }}$, Athanasios A. Koutinas ${ }^{\text {a }}$, Argyro Bekatorou ${ }^{\mathrm{a}, *}$, Vassilios Panagopoulos ${ }^{\text {a }}$, Ibrahim M. Banat ${ }^{\text {c }}$, Antonia Terpou ${ }^{\text {a }}$, Nikolaos Kopsahelis ${ }^{\mathrm{d}}$

${ }^{a}$ Department of Chemistry, University of Patras, 26500 Patras, Greece

${ }^{b}$ Department of Oenology and Beverage Technology, Eastern Macedonia and Thrace Institute of Technology, 66100 Kavala, Greece

${ }^{c}$ School of Biomedical Sciences, University of Ulster, BT52 1SA Coleraine, N. Ireland, $U K$

${ }^{d}$ Department of Food Science and Human Nutrition, Agricultural University of Athens, Iera Odos 75, 11855 Athens, Greece

*Corresponding author. Tel.: +30 2610962964; fax: +30 2610997105

E-mail address: abekatorou@ upatras.gr (A. Bekatorou) 


\section{ABSTRACT}

Enhanced single cell oil (SCO) production by the oleaginous yeast Lipomyces starkeyi DSM 70296, immobilised on delignified porous cellulose, is reported. Pure glucose media were initially used. The effects of substrate $\mathrm{pH}$ and treatment temperature were evaluated, showing that $30{ }^{\circ} \mathrm{C}$ and $\mathrm{pH} 5.0$ were the optimum conditions for SCO production by the immobilised yeast. The immobilisation technique led to increased lipid accumulation and cell growth by $44 \%$ and $8 \%$, respectively, in the glucose media, compared to free cells in suspension. This positive effect was also shown when low concentration mixed agro-industrial waste suspensions were used as substrates, leading to $85 \%$ enhanced SCO production in comparison with free cells. Higher fatty acid (HFA) analysis showed that yeast immobilization led to increased formation of unsaturated HFAs (6\%) and reduced saturated HFAs (5\%) compared to free cells.

Keywords: Single cell oil, Lipomyces starkeyi, cellulose, immobilisation, higher fatty acids 


\section{Introduction}

The use of first generation biodiesel (mainly consisting of fatty acid methyl esters produced from crop oils) led to increase of the cost of raw materials, since oilseed crops require energy and arable land competing with food and feed production.

Therefore, it has become imperative that biofuel production should depend on renewable resources such as non-food crops and agroindustrial wastes (AIW) and byproducts. Recent research efforts have also focused on biodiesel production using microbial oil (single cell oil; SCO) that accumulates in oleaginous microorganisms, which can grow on various resources such as AIW (Koutinas et al., 2014; Tsouko et al., 2016). The bioconversion of AIW into SCO can lead to decrease of biodiesel production cost with simultaneous recycling and valorisation of these wastes.

For this purpose, a variety of oleaginous microorganisms have been proposed (Leiva-Candia et al., 2014). Among them, Lipomyces starkeyi, an oleaginous yeast isolated from soil, has a lipid accumulation ability of about $65 \%$ of its dry cell weight when grown in synthetic sugar media (Anschau et al., 2014; Lin et al., 2011). It is capable of utilizing mixed sugars, including glucose, xylose, mannose, and cellobiose, and can degrade extracellular polysaccharides by secreting glycosidases (Calvey et al., 2016; Zhao et al., 2008). Efforts to produce SCO from AIW using L. starkeyi faced lower lipid accumulation productivities compared to those obtained in synthetic media, thus limiting its potential industrial applications (Ali El-Naggar et al., 2011; Yu et al., 2011).

The use of cell immobilization techniques in fermentation processes has offered numerous advantages compared to conventional free cell or enzyme systems, including improved productivities and product quality, feasibility of continuous 
processing, protection against physicochemical and shearing stresses, etc.,

(Kourkoutas et al., 2004; Liu \& Chen, 2016). Various types of materials have been proposed as carriers for cell or enzyme immobilisation, including cellulosic AIW. Among these, porous delignified wood cellulose (DC) was proved to be a significant promoter of the fermentation activity and viability of various microorganisms when used as immobilisation carrier. DCs produced by lignin removal of various plant lignocellulosics (wood, straw, husk, etc.) were shown to have a complex porous structure, including pores and tubes with sizes down to micro and nano scales (Ganatsios et al., 2014; Koutinas et al., 2012; Kumar et al., 2014).

Regarding the use of AIW for the production of valuable products, the bioconversion of mixed substrates has several advantages such as: (i) reduction of transportation and disposal costs; (ii) possibility to develop complete fermentation feedstocks without need for nutrients addition; (iii) ability to exploit AIW from lowcapacity production plants by supplying them to a central treatment plant; (iv) improvement of the nutritional value of livestock feeds; (v) production of various valuable products (Aggelopoulos et al., 2013; 2014;). Specifically, the organic load of AIW can be recovered or hydrolyzed (chemically or biologically) to produce glucose, amino acids and phosphate, which can then be (bio)transformed into valuable products such as carbon and nitrogen sources, alcohols (ethanol, butanol, 2,3butanediol), organic acids (citric, succinic, lactic, erucic, acrylic, adipic, etc.), proteins, enzymes, oils, lignin, phytochemicals, glycerol, phytosterols, antioxidants, flavonoids, carotenoids, biodegradable plastics, aroma compounds, esters, biosurfactants, prebiotic oligosaccharides, etc., (Aggelopoulos et al., 2014; Andersen et al., 2015; Leiva-Candia et al., 2014; Pleissner et al., 2016; Sharma et al., 2016). Mixed AIW substrates containing cheese whey, molasses, orange and potato 
pulp, were recently used for growth of various species (Kluyveromyces marxianus, kefir, and Saccharomyces cerevisiae), showing a promotional effect of orange pulp when added in the growth media (Aggelopoulos et al., 2013; 2014). Molasses on the other hand, is a carbohydrate-rich by-product of the sugar production industry (45$55 \%$ fermentable sugar; mainly sucrose), which is commonly used for bioethanol and baker's yeast production worldwide. It has also been extensively used for numerous other valuable fermentation products such as SCO (Sharma et al., 2016; Vieira et al., 2016), alone or mixed with other types of substrates (Andersen et al., 2015).

Based on the above studies, the aim of the present investigation was to evaluate the growth and SCO accumulation ability of the oleaginous yeast L. starkeyi, immobilised on DC, using low-sugar AIW mixtures consisting of molasses and orange pulp as substrates.

\section{Materials and methods}

\subsection{Microorganism and media}

The strain L. starkeyi DSM 70296 was preserved at $4{ }^{\circ} \mathrm{C}$ in $2 \%$ agar slopes containing

$10 \mathrm{~g} \mathrm{~L}^{-1}$ yeast extract, peptone, and D-glucose (Tsakona et al., 2014). The same medium, without the addition of agar, was used for the preparation of inocula, at 30

${ }^{\circ} \mathrm{C}$. The yeast was then cultivated, at $30{ }^{\circ} \mathrm{C}$, in synthetic glucose media containing $\left(\mathrm{g} \mathrm{L}^{-}\right.$

${ }^{1}$ ): glucose 20, $\mathrm{KH}_{2} \mathrm{PO}_{4} 7.0, \mathrm{Na}_{2} \mathrm{HPO}_{4} 2.5, \mathrm{MgSO}_{4} \cdot 7 \mathrm{H}_{2} \mathrm{O} 1.5, \mathrm{FeCl}_{3} \cdot 6 \mathrm{H}_{2} \mathrm{O} 0.15$, $\mathrm{ZnSO}_{4} \cdot 7 \mathrm{H}_{2} \mathrm{O} 0.02, \mathrm{MnSO}_{4} \cdot \mathrm{H}_{2} \mathrm{O} 0.06, \mathrm{CaCl}_{2} \cdot 2 \mathrm{H}_{2} \mathrm{O} 0.15,\left(\mathrm{NH}_{4}\right)_{2} \mathrm{SO}_{4} 1$ and yeast extract 0.5 (Tchakouteu et al., 2015). The nitrogen concentration was maintained stable by addition of yeast extract at various time intervals in order to avoid 
oleogenesis (Tapia et al., 2012). The culture was harvested by centrifugation at 4000 rpm for $10 \min$ (moisture 26\%).

The glucose media used for yeast immobilisation on DC as well as for the following cell growth/lipid accumulation experiments contained 12 and $40 \mathrm{~g} \mathrm{~L}^{-1}$ glucose, respectively.

Mixed AIW media were prepared by mixing orange juice with a diluted molasses solution of $4{ }^{\circ} \mathrm{Be}$ (Baume) hydrometer density, in order to prepare a cultivation broth containing $40 \mathrm{~g} \mathrm{~L}^{-1}$ total sugar. Orange juice was extracted from Washington Navel variety oranges (supplied from the local market). The oranges were blended for juice extraction and the solids were separated using a cheese cloth. The initial sugar concentration of the juice was $91 \mathrm{~g} \mathrm{~L}^{-1}$. Various dilutions were then prepared using sterilised, deionized water. Molasses were supplied by the B. G. Spiliopoulos S. A. Distillery (Patras, Greece). They contained 78\% solids, $42.5 \%$ total fermentable sugar and had $\mathrm{pH}$ 4.6. All media were sterilised by autoclaving for $15 \mathrm{~min}$.

\subsection{Preparation of DC and yeast immobilisation}

The DC material was prepared after delignification of sawdust by boiling with $1 \%$ $\mathrm{NaOH}$ for $3 \mathrm{~h}$. Cell immobilisation on DC took place by suspending $0.8 \mathrm{~g}$ of the harvested L. starkeyi cells in $80 \mathrm{~mL}$ of $12 \%$ glucose synthetic medium containing $1 \%$ peptone and $1 \%$ yeast extract, and mixing with $10 \mathrm{~g}$ of DC. The system was left to ferment for 6-8 $\mathrm{h}$. The biocatalyst (DC with immobilised cells) was washed with fresh glucose medium. The immobilized yeast cells were estimated to be $0.2 \mathrm{~g}$ per $10 \mathrm{~g}$ of DC. 


\subsection{Cell growth and lipid accumulation in synthetic media}

Amounts of $10.2 \mathrm{~g}$ of the immobilized biocatalyst were placed in 200-mL Erlenmeyer flasks, each containing $100 \mathrm{~mL}$ of $40 \mathrm{~g} \mathrm{~L}^{-1}$ glucose synthetic medium. The flasks were then agitated on an orbital shaker (P-Selecta Rotabit) at $180 \pm 5 \mathrm{rpm}$, and were incubated at various temperatures $\left(28,30\right.$, and $\left.32{ }^{\circ} \mathrm{C}\right)$. The experiments were carried out with media having $\mathrm{pH} 4,5$ and 6 , which was maintained stable by periodic additions of $5 \mathrm{M} \mathrm{KOH}$. The cultivation broths were analysed at various time intervals for residual glucose. The same work was carried out with $0.2 \mathrm{~g}$ of suspended yeast cells (free cells). After consumption of all sugar, the free and immobilised cells were harvested by centrifugation to estimate the produced cell mass and lipid accumulation. All experiments were performed in triplicate and the average results are presented.

\subsection{Cell growth and lipid accumulation in mixed AIW media}

In the same manner, $10.2 \mathrm{~g}$ of immobilised biocatalyst or $0.2 \mathrm{~g}$ of free yeast cells were introduced in 200-mL flasks containing $100 \mathrm{~mL}$ of either $40 \mathrm{~g} \mathrm{~L}^{-1}$ glucose medium or mixed AIW substrate. The flasks were incubated at the optimum conditions obtained by the synthetic media experiments $\left(30^{\circ} \mathrm{C}\right.$ and substrate $\left.\mathrm{pH} 5\right)$. Again, the residual sugar was monitored (sum of sucrose, glucose and fructose), and after it was all consumed, the free or immobilised cells were harvested to estimate the produced cell mass and lipid accumulation. All experiments were also performed in triplicate.

\subsection{Analytical methods}




\subsubsection{Sugar analysis by HPLC}

Residual sugars at the end of each experiment were determined on a Shimadzu LC-9A HPLC system consisting of a Shim-pack SCR-101N column (set at $60^{\circ} \mathrm{C}$ ), an LC-9A pump, an RID-6A refractive index detector, a CTO-10A column oven, and a DGU-2A degassing unit. Ultra pure water, obtained by a Milli-Q water purifier system

(resistivity $\left.18.2 \mathrm{M} \Omega \mathrm{cm}^{-1}\right)$, was used as mobile phase (0.8 mL/min). 1-Butanol $(0.1 \%$ $\mathrm{v} / \mathrm{v}$ ) was used as internal standard. The sample dilution was $1 \% \mathrm{v} / \mathrm{v}$, and the injection volume was $40 \mu \mathrm{L}$.

\subsubsection{Cell mass determination}

At the end of each cultivation experiment, the free or immobilized cells were harvested by centrifugation at $4500 \mathrm{rpm}$ for $15 \mathrm{~min}$ and washed twice with distilled water. Cell mass production was determined by weighing after drying the cells at $80{ }^{\circ} \mathrm{C}$ overnight, and expressed as g dry cell mass per $\mathrm{L}$ of substrate (cell mass yield; $\mathrm{g} \mathrm{L}^{-1}$ ).

\subsubsection{Lipid extraction}

The intracellular lipid was extracted after homogenization of the cells with $\mathrm{HCl}$ and chloroform/methanol (2:1) (1 g of cells per $20 \mathrm{~mL}$ of solvent mixture), according to Folch et al. (1957). The whole mixture was agitated for 15-20 min on an orbital shaker and then allowed to stand in a dark place for $72 \mathrm{~h}$. The extract was separated by paper filtration and evaporated on a rotary evaporator. This method allows extraction of the total lipid content, which was expressed as g lipid per g dry cell weight (SCO; $\mathrm{g} \mathrm{g}^{-1}$ dry cell wt).

\subsubsection{Fatty acid composition analysis}


The microbial oil was esterified to produce methyl esters by addition of $230 \mathrm{~mL}$ of methanol/benzene $(3: 1)$ and careful dilution of $0.8 \mathrm{~g}$ of toluene sulphuric acid into the mixture. Methyl esters were determined on a GC-8A Shimadzu gas chromatograph connected with a C-R6A Chromatopack integrator, using a Free Fatty Acid Phase (FFAP) type stainless steel column suitable for esters (10\% FFAP on Chromosorb WAW 80/100, 3m long). The carrier gas was $\mathrm{N}_{2}(20 \mathrm{~mL} / \mathrm{min})$. The injection port and the detector temperature was $250{ }^{\circ} \mathrm{C}$. The column temperature range was $160-250{ }^{\circ} \mathrm{C}(6$ ${ }^{\circ} \mathrm{C} / \mathrm{min}$ rising rate). The internal standard was anthracene $(0.7 \% \mathrm{w} / \mathrm{v})$. Amounts of $2 \mu \mathrm{L}$ of the samples were injected directly in the column. Identification of fatty acids was based on the retention times of the corresponding methyl esters.

\section{Results and Discussion}

Microbial SCO production is a promising alternative for exploitation of AIW for added-value products such as biodiesel and edible oils. However, application of such processes requires high productivities in order to maintain low production and investment costs. In this study, the growth and lipid accumulation by the oleaginous yeast $L$. starkeyi was evaluated using a mixed AIW substrate consisting of molasses and orange juice, two common food industry wastes (sugar production and citrus processing, respectively). The effect of yeast immobilization on a natural porous cellulosic material (DC) was also evaluated. The cultivation experiments were initially carried out in glucose media, at various temperature and $\mathrm{pH}$ conditions, using both free and immobilized cells. Subsequently, the mixed AIW substrate was used at the optimum conditions that were indicated by the experiments in the glucose media. 


\subsection{SCO production in glucose media}

Cell growth and SCO accumulation by immobilised $L$. starkeyi was initially studied in glucose synthetic media, in shaken cultivation experiments and under limited nitrogen conditions, in order to identify the optimum temperature and $\mathrm{pH}$ conditions. The results are presented in Table 1. It can be observed that the mean SCO yield is significantly different (One-Way ANOVA analysis; $\mathrm{P}=0.003$ ) at different substrate $\mathrm{pH}$ values. Regarding the temperature effect, the best results were obtained at $30{ }^{\circ} \mathrm{C}$, although temperature in the range $28-32{ }^{\circ} \mathrm{C}$ does not seem to have a statistically significant effect $(\mathrm{P}=0.852)$ on $\mathrm{SCO}$ production. Therefore, substrate $\mathrm{pH} 5$ and cultivation temperature $30{ }^{\circ} \mathrm{C}$ were selected as best conditions for lipid accumulation in free and immobilised yeast using AIW substrates. Similar cultivation conditions were also indicated as optimum in previous studies, regarding lipid accumulation in free L. starkeyi cells (Angerbauer et al., 2008; Lin et al., 2011; Zhao et al., 2008).

\subsection{Effect of yeast immobilisation on SCO production}

\subsubsection{Cultivation in glucose media}

SCO accumulation in L. starkeyi, free and immobilised on DC, was evaluated by cultivation experiments in glucose media $\left(40 \mathrm{~g} \mathrm{~L}^{-1}\right)$. The process kinetics, regarding sugar consumption and lipid accumulation are shown in Figure 1. After $120 \mathrm{~h}$ cultivation of the immobilised cells, cell mass reached $22.5 \mathrm{~g} \mathrm{~L}^{-1}$ and SCO production was $0.33 \mathrm{~g} \mathrm{~g}^{-1}$ (Table 2), accounting for $8.8 \%$ and $40 \%$ increase, respectively, compared to free cells. Also, residual sugar was lower by $50.7 \%$ in the case of immobilised cells. This is in accordance with previous studies that showed better 
assimilation of sugars (maltose, glucose, lactose) by cells immobilised on DC, which was explained by possible attraction of the sugars by hydrogen bonding on the DC surface and continuous pumping towards the cells (Ganatsios et al., 2014; Koutinas et al., 2012).

\subsubsection{Cultivation in mixed AIW}

Enhanced growth and SCO accumulation by the immobilised L. starkeyi, compared to free cells, was also observed in the mixed AIW substrate. Specifically, 17\% higher cell mass production, 52\% increase of SCO accumulation, and lower residual sugar were obtained (Table 2). These results are encouraging for efficient AIW exploitation for SCO production. Previous studies for exploitation of AIW substrates for SCO production reported lower cell mass and oil yields (Table 3). Therefore, cell immobilisation on natural low cost carriers such as DC, favours industrial opportunities for SCO production by renewable sources such as AIW.

\subsubsection{Higher fatty acid composition of SCO}

SCO applications in sectors such as edible oils and biofuels production, require suitable composition of fatty acids, regarding nutritional value and technological features. The lipids obtained by free or immobilised L. starkeyi cells were transesterified with methanol and then analyzed by GC. The analysis showed that the SCO glycerides contained saturated higher fatty acid (HFAs) such as palmitic and stearic acid, while unsaturated HFAs included oleic, palmitoleic and linoleic acids (Table 4). Yeast immobilisation on DC increased by $6 \%$ the unsaturated HFAs and reduced by $5 \%$ the saturated HFAs, indicating potential of the technique to improve the nutritional value of the oil. The 54\% unsaturated HFAs content in the SCO 
produced by immobilised L. starkeyi, as compared with soy oil, sunflower oil and corn oil, encourages research for the use of microbial SCO as edible oil.

\subsection{Discussion}

The promotional effect of the proposed immobilisation technique on $L$. starkeyi growth and lipid accumulation, was validated in both synthetic glucose media and in mixed AIW that contained orange juice and molasses. The yeast L. starkeyi was selected due to its ability to utilize various sugars, including glucose and xylose (Zhao et al., 2008), which are among the main sugars contained in wastes of the citrus and sugar industries as well as in other types of biomass.

Lipid accumulation is known to be significantly affected by the presence of specific metals in the substrate (e.g. Mg, K, Na, Fe, Zn, Co). It is also affected by limited nitrogen concentration that inhibits the activation of the NAD isocitrate dehydrogenase resulting in accumulation of citrate and increased acetyl-CoA and lipid synthesis (Tsakona et al., 2014; Shuib et al., 2014; Calvey at al., 2016). Therefore, the results of this study indicate that the used AIW contained sufficient metal and nitrogen sources for lipid accumulation in L. starkeyi.

Previous studies have also shown that cellulosic materials have an affinity for metal complexation (Kumar et al., 2017), which can lead to increased availability of the metal ions to the cells that are attached on DC. This, in combination with the naturally present metal ions in the mixed AIW, and the promotional effect of DC on the process, can lead to good lipid accumulation yields using the proposed renewable substrate and immobilisation technique.

Regarding the promotional effect of DC on bioprocessing, it has been previously 
shown that its use as immobilization carrier can lead to increased productivities in alcoholic and lactic acid fermentations (Koutinas et al., 2012; Kourkoutas et al., 2004; Ganatsios et al., 2014). Specifically, in these studies, calculation of the activation energy of alcoholic fermentations at low temperatures showed that it was reduced by an average $42 \%$ when cells immobilized on DC were used.

Finally, the increased formation of oleic acid and the reduction of saturated HFAs are also of technological importance because they can contribute to the use of the produced SCO as edible oil. The proposed process is feasible, due to its low cost, simplicity, and environmentally friendly character.

\section{Conclusions}

The optimum conditions for growth and lipid accumulation of L. starkeyi cells immobilised on DC were $30{ }^{\circ} \mathrm{C}$ cultivation temperature and substrate $\mathrm{pH} 5$. Comparison of immobilised and free cells in glucose media and in mixed AIW (molasses and orange juice) revealed the positive effect of the immobilisation technique on both growth and lipid accumulation. Immobilisation also increased the unsaturated HFAs and reduced the saturated HFAs content of the produced oil, leading to improvement of its nutritional value. The proposed process using renewable resources has potential for industrial application and further research is needed on SCO production for food uses.

\section{Acknowledgments}

This research has been co-financed by the European Union (European Social Fund- 
ESF) and Greek national funds through the Operational Program "Education and Lifelong Learning” of the National Strategic Reference Framework (NSRF) Research Funding Program: Heracleitus II. Investing in knowledge society through the European Social Fund.

\section{References}

Aggelopoulos, T., Bekatorou, A., Pandey, A., Kanellaki, M., Koutinas, A.A., 2013.

Discarded oranges and brewer's spent grains as promoting ingredients for microbial growth by submerged and solid state fermentation of agro-industrial waste mixtures. Appl. Biochem. Biotech. 170(8), 1885-1895.

Aggelopoulos, T., Katsieris, K., Bekatorou, A., Pandey, A., Banat, I.M., Koutinas, A.A., 2014. Solid state fermentation of food waste mixtures for single cell protein, aroma volatiles and fat production. Food Chem. 145, 710-716.

Ali El-Naggar, N.E.A., El-Hersh, M.S., El-Fadaly, H.A., Saber, W.I.A., 2011. Bioconversion of some agro-industrial by-products into single cell oil using Candida albicans NRRL Y-12983 and Lipomyces starkeyi NRRL Y-11557. Res. J. Microbiol. 6(11), 784-795.

Andersen, R.L., Jensen, K.M., Mikkelsen, M.J., 2015. Continuous ethanol fermentation of pretreated lignocellulosic biomasses, waste biomasses, molasses and syrup using the anaerobic, thermophilic bacterium Thermoanaerobacter italicus pentocrobe 411. Plos One, 10(8).

Angerbauer, C., Siebenhofer, M., Mittelbach, M., Guebitz, G.M. (2008). Conversion of sewage sludge into lipids by Lipomyces starkeyi for biodiesel production. Bioresour. Technol. 99(8), 3051-3056. 
Anschau, A., Franco, T.T., 2015. Cell mass energetic yields of fed-batch culture by Lipomyces starkeyi. Bioproc. Biosyst. Eng. 38(8), 1517-1525.

Anschau, A., Xavier, M.C.A., Hernalsteens, S., Franco, T.T., 2014. Effect of feeding strategies on lipid production by Lipomyces starkeyi. Bioresour. Technol. 157, 214222.

Calvey, C.H., Su, Y.-K., Willis, L.B., McGee, M., Jeffries, T.W. 2016. Nitrogen limitation, oxygen limitation, and lipid accumulation in Lipomyces starkeyi. Bioresour. Technol. 200, 780-788.

Folch, J., Lees, M., Sloane Stanley, G.H., 1957. A simple method for the isolation and purification of total lipides from animal tissues. J. Biol. Chem. 226(1), 497-509.

Ganatsios, V., Koutinas, A.A., Bekatorou, A., Kanellaki, M., Nigam, P., 2014. Promotion of maltose fermentation at extremely low temperatures using a cryotolerant Sacharomyces cerevisiae strain immobilized on porous cellulosic material. Enzyme Microb. Tech. 66, 56-59.

Gong, Z., Wang, Q., Shen, H., Hu, C., Jin, G., Zhao, Z.K., 2012. Co-fermentation of cellobiose and xylose by Lipomyces starkeyi for lipid production. Bioresour. Technol. 117, 20-24.

Huang, C., Chen, X.F., Yang, X.Y., Xiong, L., Lin, X.Q., Yang, J., Wang, B., Chen, X.D., 2014. Bioconversion of corncob acid hydrolysate into microbial oil by the Oleaginous yeast Lipomyces starkeyi. Appl. Biochem. Biotech. 172(4), 2197-204.

Huang, L., Zhang, B., Gao, B., Sun, G., 2011. Application of fishmeal wastewater as a potential low-cost medium for lipid production by Lipomyces starkeyi HL. Environ. Technol. 33(15-16), 1975-81. 
Kourkoutas, Y., Bekatorou, A., Banat, I.M., Marchant, R., Koutinas, A.A., 2004. Immobilization technologies and support materials suitable in alcohol beverages production: a review. Food Microbiol. 21(4), 377-397.

Koutinas, A.A., Chatzifragkou, A., Kopsahelis, N., Papanikolaou, S., Kookos, I.K., 2014. Design and techno-economic evaluation of microbial oil production as a renewable resource for biodiesel and oleochemical production. Fuel, 116, 566-577.

Koutinas, A.A., Sypsas, V., Kandylis, P., Michelis, A., Bekatorou, A., Kourkoutas, Y., Kordulis, C., Lycourghiotis, A., Banat, I.M., Nigam, P., Marchant, R., Giannouli, M., Yianoulis, P., 2012. Nano-tubular cellulose for bioprocess technology development. Plos One, 7(4).

Kumar, R., Sharma, R.K., Singh, A.P., 2017. Cellulose based grafted biosorbents Journey from lignocellulose biomass to toxic metal ions sorption applications - A review. J. Mol. Liq. 232, 62-93.

Kumar, M.N., Gialleli, A.I., Masson, J.B., Kandylis, P., Bekatorou, A., Koutinas, A.A., Kanellaki, M., 2014. Lactic acid fermentation by cells immobilised on various porous cellulosic materials and their alginate/poly-lactic acid composites. Bioresour. Technol. 165(C), 332-335.

Leiva-Candia, D.E., Pinzi, S., Redel-Macías, M.D., Koutinas, A., Webb, C., Dorado, M.P., 2014. The potential for agro-industrial waste utilization using oleaginous yeast for the production of biodiesel. Fuel, 123, 33-42.

Lin, J., Shen, H., Tan, H., Zhao, X., Wu, S., Hu, C., Zhao, Z.K., 2011. Lipid production by Lipomyces starkeyi cells in glucose solution without auxiliary nutrients. J. Biotechnol. 152(4), 184-188. 
Liu, J.-X., Yue, Q.-Y., Gao, B.-Y., Ma, Z.-H., Zhang, P.-D., 2012. Microbial treatment of the monosodium glutamate wastewater by Lipomyces starkeyi to produce microbial lipid. Bioresour. Technol. 106, 69-73.

Liu, Y., Chen, J.Y., 2016. Enzyme immobilization on cellulose matrixes. J. Bioact. Compat. Pol. 31(6), 553-567.

Matsakas, L., Sterioti, A.-A., Rova, U., Christakopoulos, P., 2014. Use of dried sweet sorghum for the efficient production of lipids by the yeast Lipomyces starkeyi CBS 1807. Ind. Crop. Prod. 62, 367-372.

Pleissner, D., Qi, Q., Gao, C., Rivero, C.P., Webb, C., Lin, C.S.K., Venus, J., 2016. Valorization of organic residues for the production of added value chemicals: A contribution to the bio-based economy. Biochem. Eng. J. 116, 3-16.

Sharma, M., Patel, S.N., Lata, K., Singh, U., Krishania, M., Sangwan, R.S., Singh, S.P., 2016. A novel approach of integrated bioprocessing of cane molasses for production of prebiotic and functional bioproducts. Bioresour. Technol. 219, 311318.

Shuib S., Nawi W.N.N.W., Taha E.M., Omar O., Kader A.J.A., Kalil M.S., Hamid A.A., 2014. Strategic feeding of ammonium and metal ions for enhanced GLA-rich lipid accumulation in Cunninghamella bainieri 2A1. The Sci. World J., ID 173574, $8 \mathrm{p}$.

Tapia, V.E., Anschau, A., Coradini, A.L., T, T.F., Deckmann, A.C., 2012. Optimization of lipid production by the oleaginous yeast Lipomyces starkeyi by random mutagenesis coupled to cerulenin screening. AMB Express, 2(1), 64.

Tchakouteu, S.S., Kalantzi, O., Gardeli, C., Koutinas, A.A., Aggelis, G., Papanikolaou, S., 2015. Lipid production by yeasts growing on biodiesel-derived 
crude glycerol: Strain selection and impact of substrate concentration on the fermentation efficiency. J. Appl. Microbiol. 118(4), 911-927.

Tsakona, S., Kopsahelis, N., Chatzifragkou, A., Papanikolaou, S., Kookos, I.K., Koutinas, A.A., 2014. Formulation of fermentation media from flour-rich waste streams for microbial lipid production by Lipomyces starkeyi. J. Biotechnol. 189, $36-45$.

Tsouko, E., Papanikolaou, S., Koutinas, A.A., 2016. Production of fuels from microbial oil using oleaginous microorganisms. in: Handbook of Biofuels Production (Second Edition), Woodhead Publishing, pp. 201-236.

Vieira, J.P.F., Ienczak, J.L., Costa, P.S., Rossell, C.E.V., Franco, T.T., Pradella, J.G.C., 2016. Single cell oil production integrated to a sugarcane-mill: Conceptual design, process specifications and economic analysis using molasses as raw material. Ind. Crop. Prod. 89, 478-485.

Yu, X., Zheng, Y., Dorgan, K.M., Chen, S., 2011. Oil production by oleaginous yeasts using the hydrolysate from pretreatment of wheat straw with dilute sulfuric acid. Bioresour. Technol. 102(10), 6134-6140.

Zhao, X., Kong, X., Hua, Y., Feng, B., Zhao, Z., 2008. Medium optimization for lipid production through co-fermentation of glucose and xylose by the oleaginous yeast Lipomyces starkeyi. Eur. J. Lipid Sci. Tech. 110(5), 405-412. 


\section{Figure captions}

Figure 1. Glucose consumption and SCO accumulation by immobilised and free $L$. starkeyi cells in synthetic glucose media. 


\section{Table 1}

Effect of $\mathrm{pH}$ and temperature on SCO production in glucose media $\left(40 \mathrm{~g} \mathrm{~L}^{-1}\right)$ by $L$. starkeyi immobilized on DC.

\begin{tabular}{ccc}
\hline Substrate $\mathrm{pH}$ & Cultivation temperature $\left({ }^{\circ} \mathrm{C}\right)$ & $\mathrm{SCO}\left(\mathrm{g} \mathrm{g}^{-1}\right.$ dry cell wt $)$ \\
\hline 6 & 32 & $0.19 \pm 0.07$ \\
& 30 & $0.23 \pm 0.06$ \\
& 28 & $0.18 \pm 0.10$ \\
\hline 5 & 32 & $0.24 \pm 0.07$ \\
& 30 & $0.31 \pm 0.09$ \\
& 28 & $0.28 \pm 0.07$ \\
\hline & 32 & $0.12 \pm 0.05$ \\
& 30 & $0.16 \pm 0.06$ \\
& 28 & $0.10 \pm 0.05$ \\
\hline
\end{tabular}




\section{Table 2}

Cell mass yield and SCO production by free cells and immobilized L. starkeyi cells grown in glucose media $\left(40 \mathrm{~g} \mathrm{~L}^{-1}\right)$ and in mixed AIW, at $30{ }^{\circ} \mathrm{C}$ and substrate $\mathrm{pH} 5$.

\begin{tabular}{|c|c|c|c|c|}
\hline & $\begin{array}{c}\text { Cultivation } \\
\text { time (h) }\end{array}$ & $\begin{array}{c}\text { Cell mass } \\
\text { yield }\left(\mathrm{g} \mathrm{L}^{-1}\right)\end{array}$ & $\begin{array}{l}\mathrm{SCO}\left(\mathrm{g} \mathrm{g}^{-1}\right. \\
\text { dry cell } w \mathrm{t})\end{array}$ & $\begin{array}{c}\text { Residual sugar* } \\
\left(\mathrm{g} \mathrm{L}^{-1}\right)\end{array}$ \\
\hline \multicolumn{5}{|l|}{ Glucose media } \\
\hline Free cells & 120 & $20.5 \pm 0.82$ & $0.23 \pm 0.03$ & $1.96 \pm 0.94$ \\
\hline Immobilized cells & 120 & $22.5 \pm 0.91$ & $0.33 \pm 0.05$ & $1.30 \pm 0.65$ \\
\hline \multicolumn{5}{|l|}{ AIW media } \\
\hline Free cells & 168 & $22.23 \pm 1.15$ & $0.25 \pm 0.04$ & $2.68 \pm 0.51$ \\
\hline Immobilized cells & 168 & $26 \pm 1.08$ & $0.38 \pm 0.05$ & $0.83 \pm 0.65$ \\
\hline
\end{tabular}

* Sum of residual sucrose, glucose and fructose in the fermented substrates 


\section{Table 3}

Comparison of the results of this study with those reported in the literature regarding the use of AIW for SCO production by the oleaginous yeast L. starkeyi.

\begin{tabular}{|c|c|c|c|c|c|}
\hline Substrate & $\begin{array}{l}\text { Initial sugar } \\
\left(\mathrm{g} \mathrm{L}^{-1}\right)\end{array}$ & $\begin{array}{l}\text { Sugar } \\
\text { consumed } \\
\left(\mathrm{g} \mathrm{L}^{-1}\right)\end{array}$ & $\begin{array}{l}\text { Cell mass } \\
\text { production } \\
\left(\mathrm{g} \mathrm{L}^{-1}\right)\end{array}$ & (\% dry cell wt) & References \\
\hline \multicolumn{6}{|l|}{ Free cells } \\
\hline Potato peels & - & 33.1 & 6.6 & 12.12 & Ali El-Naggar et al., 2011 \\
\hline Cane molasses & - & 38.3 & 7.4 & 16.22 & Ali El-Naggar et al., 2011 \\
\hline Beet molasses & - & 40.4 & 8.2 & 14.63 & Ali El-Naggar et al., 2011 \\
\hline Tomato peels & - & 35.6 & 5.4 & 11.11 & Ali El-Naggar et al., 2011 \\
\hline Squash peels & - & 29.9 & 4.9 & 12.24 & Ali El-Naggar et al., 2011 \\
\hline Glucose syrup & - & 35.6 & 8.5 & 16.47 & Ali El-Naggar et al., 2011 \\
\hline Wheat straw hydrolysate & $29.2-21.7^{\mathrm{a}}$ & - & $12.7-14.7$ & $29.1-31.2$ & Yu et al., 2011 \\
\hline Fishmeal wastewater ${ }^{b}$ & - & - & 8.6 & 21.5 & Huang et al., 2011 \\
\hline Corncob hydrolysate & 42.3 & - & 17.2 & 47.0 & Huang et al., 2014 \\
\hline Xylose + urea & $60+1.03$ & & 94.6 & 37.4 & Anschau and Franco, 2015 \\
\hline Cellobiose & 70 & & 27.9 & 50 & Gong et al., 2012 \\
\hline $\begin{array}{l}\text { Flour-rich waste } \\
\text { hydrolysate }\end{array}$ & 105 & & 109.8 & 58.7 & Tsakona et al., 2014 \\
\hline $\begin{array}{l}\text { Monosodium glutamate } \\
\text { wastewater }^{c}\end{array}$ & & - & 4.6 & 24.7 & Liu et al., 2012 \\
\hline $\begin{array}{l}\text { Saccharified sweet } \\
\text { sorghum stalks }^{\mathrm{d}}\end{array}$ & & & 22 & 29.5 & Matsakas et al., 2014 \\
\hline \multicolumn{6}{|l|}{ Cells immobilized on DC } \\
\hline Mixed AIW & 40 & & 26 & 37 & This study \\
\hline
\end{tabular}




\section{Table 4}

Fatty acid composition (\%) of SCO produced by free and immobilised L. starkeyi grown in mixed AIW, at $30^{\circ} \mathrm{C}$ and substrate $\mathrm{pH} 5$.

\section{Fatty acids}

\begin{tabular}{rccccccc} 
& Palmitic & Palmitoleic & Stearic & Oleic & Linoleic & Saturated & Unsaturated \\
\hline Free cells & 36.0 & 2.5 & 12.0 & 45.0 & 3.5 & 48.0 & 51.0 \\
Immobilized cells & 34.0 & 2.7 & 11.5 & 49.0 & 2.4 & 45.5 & 54.1 \\
\hline
\end{tabular}




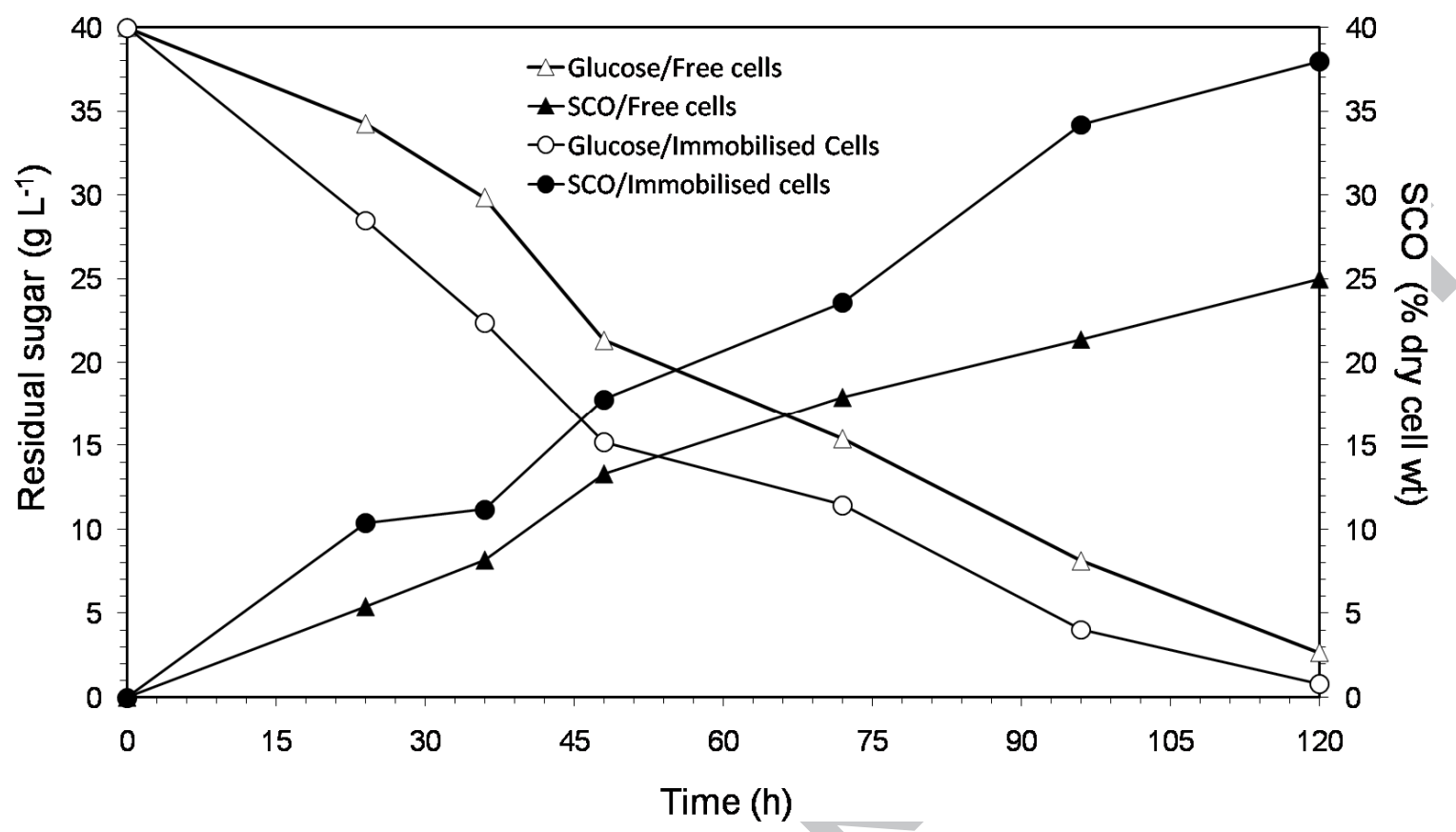

Fig. 1 


\section{Highlights}

- Growth and SCO production by L. starkeyi immobilised on delignified cellulose

- Glucose and mixed AIW (molasses/orange juice) substrates were used

- $\quad 30{ }^{\circ} \mathrm{C}$ and $\mathrm{pH} 5$ were the best conditions for both growth and SCO production

- $85 \%$ enhanced SCO production by the immobilized cells in the mixed AIW substrate

- $6 \%$ increase of unsaturated HFAs of the SCO produced by the immobilized cells 


\section{SCO production by immobilized Lipomyces starkeyi using mixed agroindustrial wastes (AIW)}

Delignified Wood Cellulose (DC)

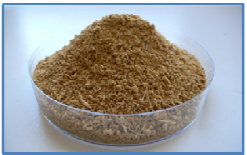

$$
\pm
$$

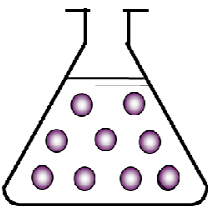

L. starkeyi DSM 70296

$+12 \%$ glucose medium (6-8 H contact)

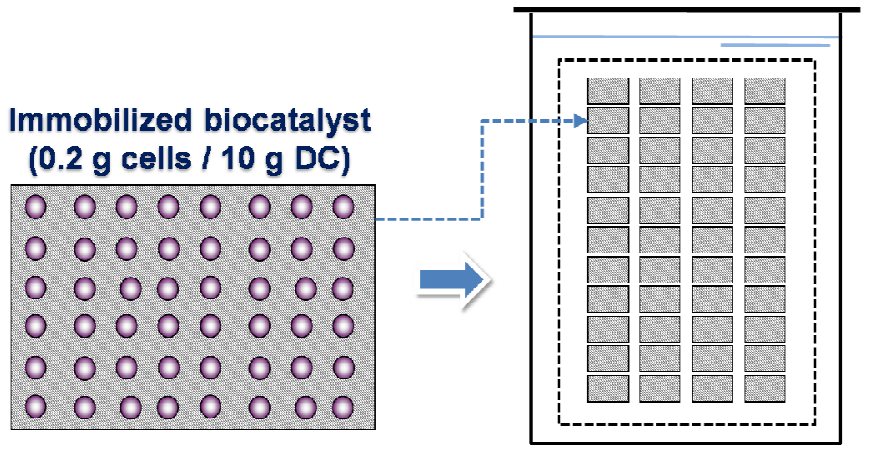

Bioreactor with immobilised L. starkeyi cells

$\checkmark 85 \%$ enhanced SCO production by the immobilized cells

$\checkmark 6 \%$ increase of unsaturated HFAs of the SCO produced by the immobilized cells 